\title{
SAUROPODS OF THE ITAPECURU GROUP (LOWER/MIDDLE ALBIAN), SÃO LUÍS-GRAJAÚ BASIN, MARANHÃO STATE, BRAZIL
}

\author{
DARCILÉA FERREIRA CASTRO \\ IG, USP, Rua do Lago, 562, 05508-900, São Paulo, SP, Brazil.darcicastro@yahoo.com.br \\ REINALDO J. BERTINI \\ IGCE, UNESP Campus de Rio Claro, 13506-900, SP, Brazil.rbertini@rc.unesp.br \\ RODRIGO MILONI SANTUCCI \\ Departamento Nacional de Produção Mineral, SAN Quadra 01 Bloco B, 70041-903, DF, Brazil. \\ rodrigoms_00@yahoo.com \\ MANUELALFREDO MEDEIROS \\ Departamento de Biologia, UFMA, Campus do Bacanga, 65080-040, São Luís, MA, Brazil.alf@elo.com.br
}

\begin{abstract}
In this paper, new sauropod remains from the lower/middle Albian of the Itapecuru Group, São LuísGrajaú Basin, Maranhão State (Brazil) are described. The material comprises vertebral centra, fragments of neural arches and a fragment of the proximal end of a humerus of limited diagnostic value. Morphological analyses of these elements indicate the presence of titanosaur sauropods and taxa related to the Rebbachisauridae. Sauropods are documented in the lower/middle Albian deposits assigned to the 'Undifferentiated Unit' for the first time. Previous occurrences of these herbivores are known from Cenomanian rocks of the Alcântara Formation, which overlays the Undifferentiated Unit. Although fragmentary, the reported fossils extend the record of sauropods in Brazilian Cretaceous deposits.
\end{abstract}

Key words: Dinosaur, sauropods, Titanosauria, Itapecuru Group, Albian.

RESUMO - Este trabalho descreve fósseis de saurópodos do Albiano inferior/médio (Grupo Itapecuru), na bacia São LuísGrajaú, Estado do Maranhão. O material está representado por centros e fragmentos de vértebras, fragmentos de arco neural e fragmento proximal de úmero de valor diagnóstico limitado. Análises das características morfológicas dos elementos ósseos sugerem a ocorrência de saurópodos Titanosauria e de grupos associados aos Rebbachisauridae. Pela primeira vez são registrados saurópodos nos depósitos do Albiano inferior/médio referidos à "Unidade Indiferenciada". Ocorrências anteriores destes herbívoros foram reconhecidas em rochas cenomanianas da Formação Alcântara, sobreposta a esta unidade. Os fósseis aqui relatados, apesar de mostrarem-se bastante fragmentados, permitiram a ampliação de registro de dinossauros saurópodos em depósitos cretáceos brasileiros.

Palavras-chave: Dinossauro, saurópodos, Titanosauria, Grupo Itapecuru, Albiano.

\section{INTRODUCTION}

The São Luís-Grajaú Basin (Figure 1) covers an area of about $250,000 \mathrm{~km}^{2}$ in the center-north portion of Maranhão State (Góes \& Rossetti, 2001; Rossetti, 2003). This basin encompasses the Itapecuru Group, which is divided into the 'Undifferentiated Unit' and Alcântara and Cujupe formations, ranging from the lower Albian to the lower Campanian (Pedrão et al., 1993a, 1993b; Rossetti \& Truckenbrodt, 1997) (Figure 2). The Undifferentiated Unit is poorly understood from both geological and paleontological aspects. Considering that the record of Eocretaceous sauropods in Brazil is rare and the potential for new findings in these deposits, the Undifferentiated Unit can play an important role in the understanding of sauropod evolution throughout the Lower/ Upper Cretaceous boundary in Brazil.

Regarding the fossil vertebrates, the Alcântara Formation is the richest unit within the Itapecuru Group, which includes fishes, turtles, crocodylomorphs, theropods and sauropods (Castro et al., 2004; Dutra \& Malabarba, 2001; Medeiros \& Schultz, 2001). More recently, desarticulated fossil remains, mainly sauropod fragments, have been recorded from deposits assigned to the Undifferentiated Unit, which is overlaid by the Alcântara Formation (Castro et al., 2005).

In this paper we describe and compare these new sauropod remains with other sauropods described in the literature. 


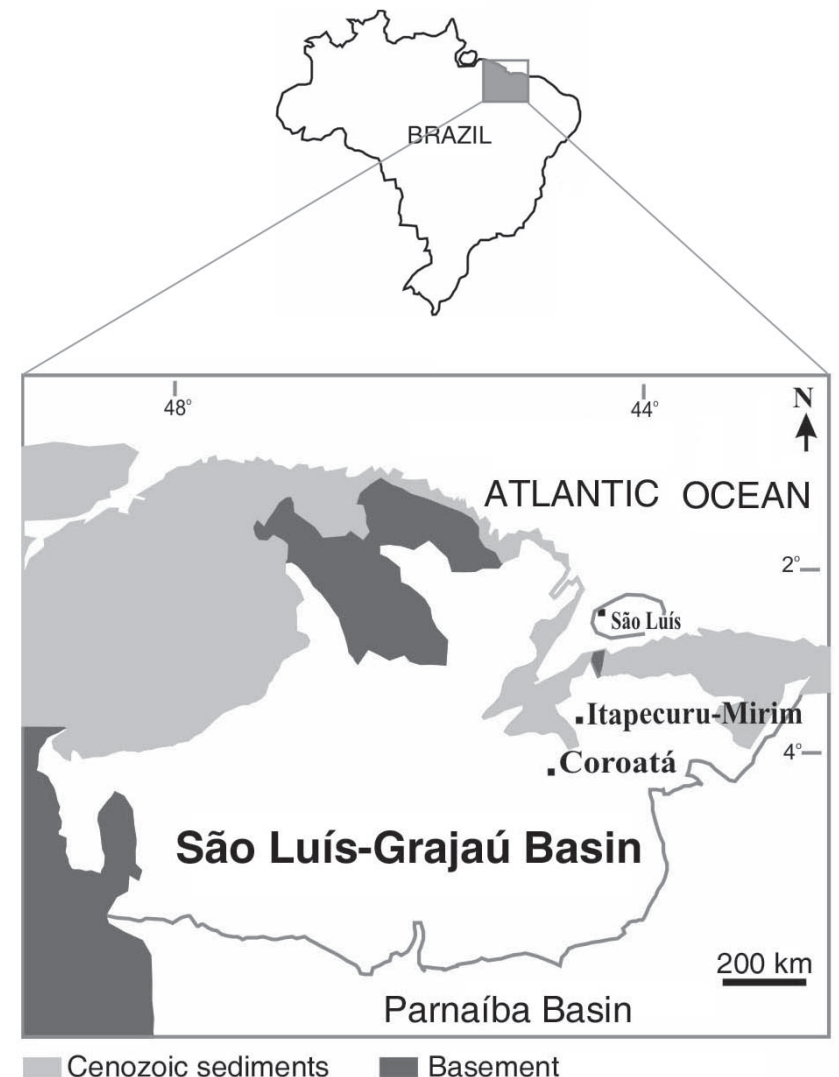

Figure 1. São Luís-Grajaú Basin in the northern part of Maranhão State, including some localities where Cretaceous rocks outcrop and the main city São Luís (adapted from Rossetti, 2001).

\section{MATERIAL AND METHODS}

The fossils described herein are housed at Casa de Cultura do Município de Coroatá (CCC), Coroatá Municipality, in the State of Maranhão. They have been collected randomly by landowners from three outcrops near the bank of a tributary creek of the Itapecuru River, in Santo Izídio, near Coroatá located in the central-north portion of the state (Figure 1).

\section{SYSTEMATIC PALAEONTOLOGY}

DINOSAURIA Owen, 1842

SAUROPODA Marsh, 1878

TITANOSAURIA Bonaparte \& Coria, 1997

Material. CCC 005, CCC 010, CCC 053, CCC 074 (Figure 3). Description. CCC 053 corresponds to an incomplete dorsal centrum (Figure 3A) with part of the posterior end. The pneumatic tissue is well developed and, in cross-sectional view, the internal spaces (coels) decrease in size toward the mid-portion of the vertebral body. The septa which separate these coels are thin, but there is no sign of interconnection among them. In dorsal view, the coels are elongated and parallel to the sagittal axis of the centrum.

CCC 074 is a fragment of the anterior dorsal vertebra (Figure 3B) has a pneumatic tissue similar to that described in CCC 053. In this vertebra, a large chamber which is regarded here as a pleurocoel can be observed. In anterior view, the internal coels are elongated and radially arranged in the centrum. The internal coels increase in size toward the pleurocoel. In dorsal view, the internal coels are elongated and aligned to the sagittal plane.

The specimen CCC 010 is a mid-anterior caudal vertebra (Figure 3C) that is badly damaged. The centrum is longer than high with no bone tissue. The anterior and posterior ends are both concave. The lateral faces are high and slightly concave. The ventral face is anteroposteriorly flat with incipient lateral ridges. Dorsally, remains of the neural arch indicate that it was placed on the anteriormost portion of the centrum like in other titanosaurs (Salgado et al., 1997). There are no signs of posterior depressions for hemal arch attachment.

CCC 005 is a fragmentary proximal end of a right humerus (Figures 3D1-2). The proximal and lateral margins meet in a right angle. Although not completely preserved, the medial margin shows signs of being strongly expanded. The deltoid crest is not preserved. The anterior and the posterior faces are concave, but in the latter the concavity is slightly developed.

\section{DIPLODOCOIDEA Marsh, 1884}

Material. CCC 017, CCC 030, CCC 060 (Figure 4).

Description. The specimen CCC 017 is a fragment of neural arch and neural spine and is tentatively identified as a posterior dorsal vertebra (Figure 4A). The distal end of the neural spine and the prezygapophyses are lacking. The neural spine is slender and anteroposteriorly short. It is formed by the cross resulting from the joining of the prespinal lamina,

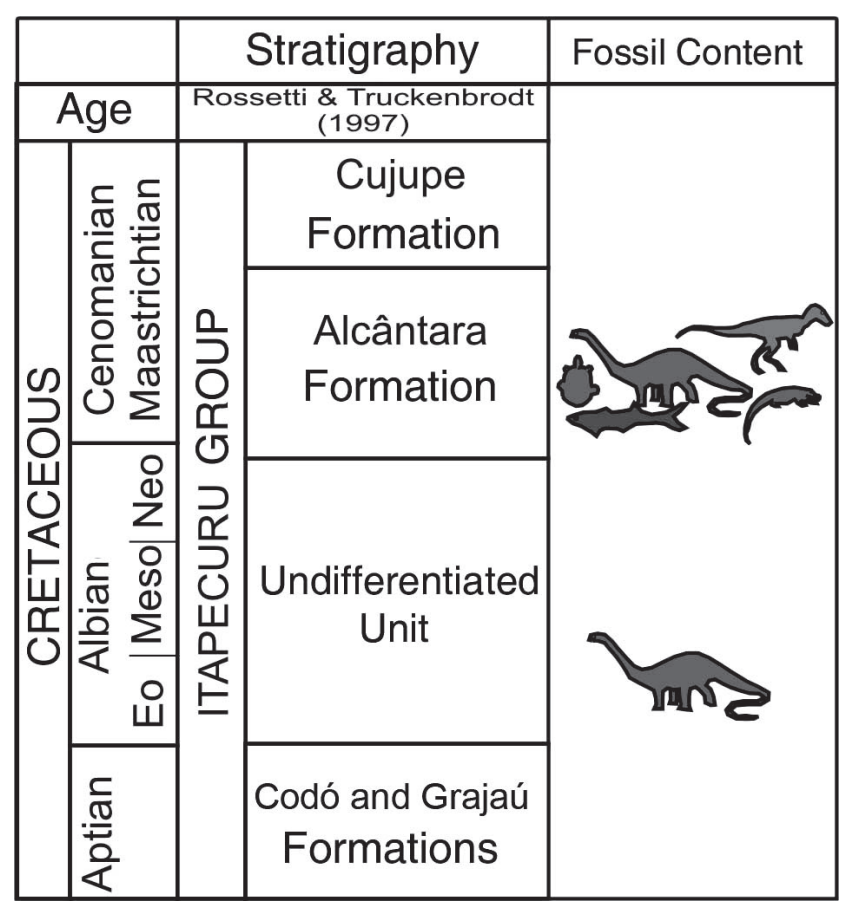

Figure 2. Stratigraphical column of the São Luís-Grajaú Basin (modified from Rossetti \& Truckenbrodt, 1997). 
postspinal lamina, and the two laminae interpreted as the spinodiapophyseal laminae. The left spinodiapophyseal lamina is well preserved, well developed, slender, and curved toward the prespinal lamina. The right one is deformed so that it overlays the prespinal lamina. The prespinal lamina is broken at its base but, as far as can be observed, it is well developed and not bifurcated. The postspinal lamina is more developed than the prespinal one. It is slender and expanded laterally in its posterior extension so that in dorsal view it has a trapezoidal shape. The left side of the neural spine has an incipient accessory lamina which links the spinodipophyseal lamina to the spinopostzygapophyseal lamina. This accessory lamina only occurs on the left side and is nearly vertical. The prezygapophyses are short with small articular facets. They are reinforced by the spinopostzygapophyseal laminae which also contact the postspinal lamina. A deep pit can be observed among the spinopostzygapophyseal laminae and the postspinal lamina. The latter lamina extends into this pit. The ventral margin of the postzygapophyses, where they contact each other, there is a worn protuberance which seems to correspond to the hyposphene.

CCC 030 is a fragmentary neural arch (Figure 4B) regarded as belonging to a dorsal vertebra with part of the contact area with the centrum and the proximal half of the neural spine preserved. The neural spine is anteroposteriorly compressed and elliptical in cross-section. The postspinal lamina is stout and well developed. The postzygapophyses are not preserved, but the broken area where they should be placed is diamond-shaped. In anterior view, the neural spine has two well-developed accessory laminae that meet at the base of the neural spine. At the side of each accessory lamina there is a deep pit.

The specimen CCC 060 (Figure 4C) is tentatively regarded as an anterior caudal neural spine. It is slightly deformed and anteroposteriorly compressed. The pre- and postspinal laminae are both simple, slender, and well developed; however, the latter is more developed than the former. In anterior view, the left side of the neural spine has a ridge that is subparallel to the prespinal lamina.
A1
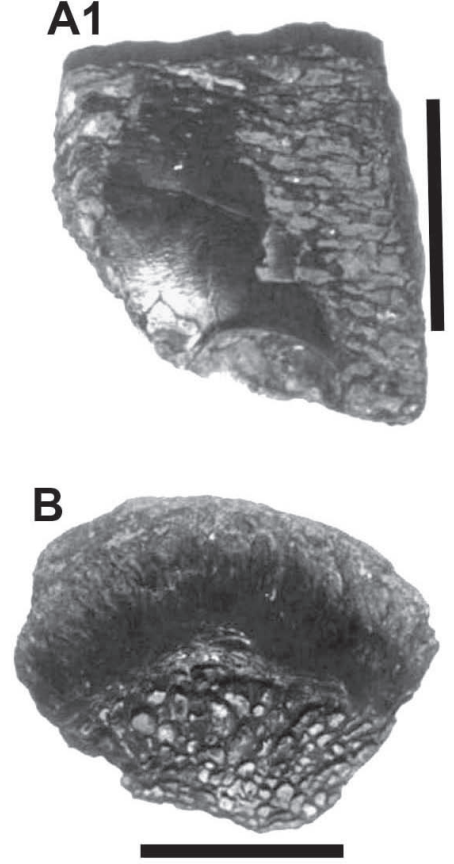

C3

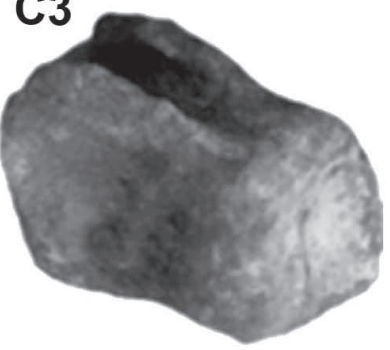

A2

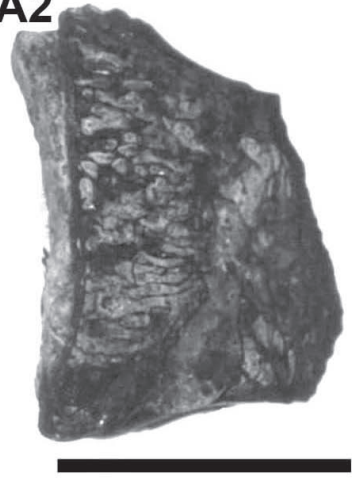

C1

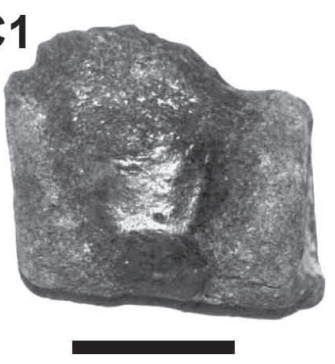

D1

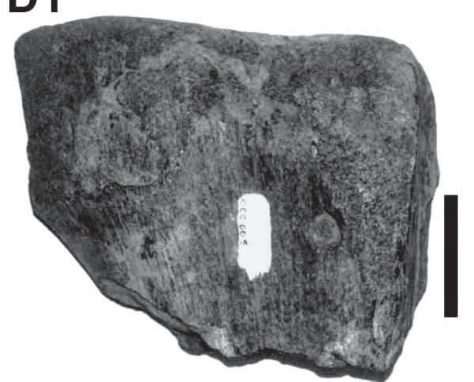

A3

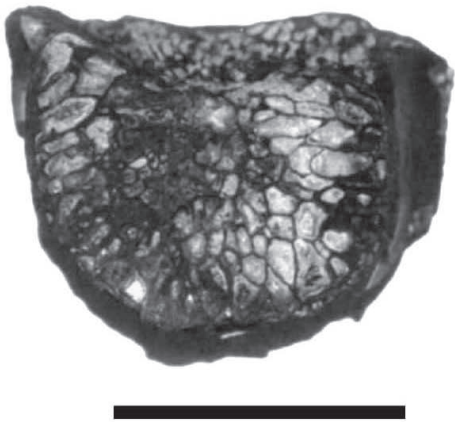

C2

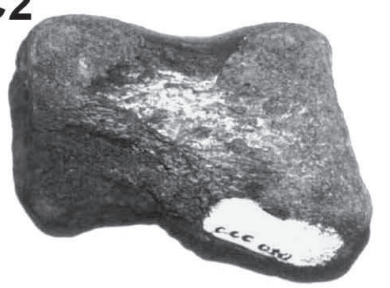

D2

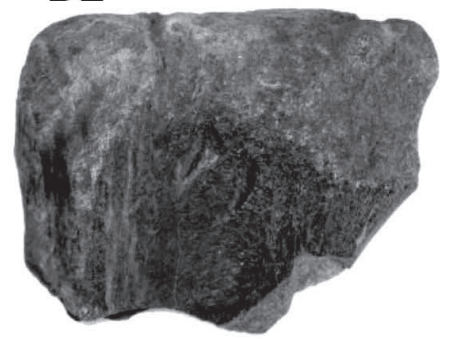

Figure 3. Titanosauria. A, CCC 053, fragment of vertebral dorsal centrum in left lateral (A1), right lateral (A2) and anterior (A3) views, scale bar = $5 \mathrm{~cm}$; B,CCC 074, fragment of vertebral dorsal centrum in anterior view, scale bar = $5 \mathrm{~cm}$; C, CCC 010 , vertebral caudal centrum in right lateral (C1), left lateral (C2) and latero-posterior (C3) views, scale bar $=5 \mathrm{~cm}$; D, CCC 005, fragment of proximal epiphysis of right humerus in posterior (D1) and anterior (D2) views, scale bar $=10 \mathrm{~cm}$. 

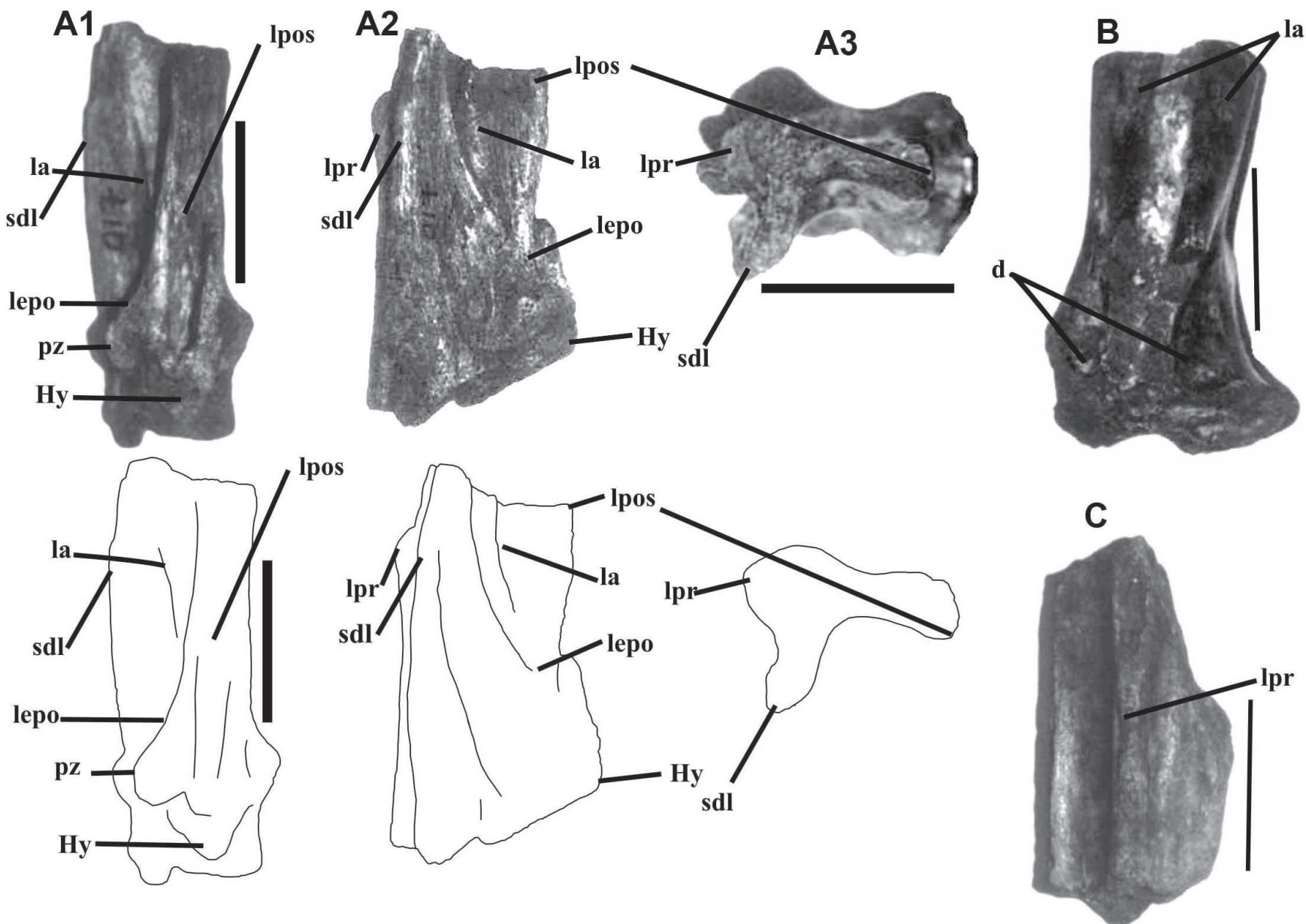

Figure 4. Rebbachisauridae. A, CCC 017, fragment of arch neural, probably of posterior dorsal or anterior caudal vertebrae, in posterior (A1), left lateral (A2) and dorsal (A3) views; B, CCC 030, fragment of neural arch in anterior view; C, CCC 060, fragment of neural spine in lateral view, with schematic drawings. Abbreviations: hy, hyposphene; pz, postzygapophysis; al, accessory lamina; psl, postspinal lamina; prl, prespinal lamina; spol, spinopostzygapophyseal lamina; $\mathbf{f}$, fossa; sdl, spinodiapophyseal lamina. Scale bars $=5 \mathrm{~cm}$.

\section{DISCUSSION}

Although incomplete and sometimes badly damaged, the sauropod remains found in the Undifferentiated Unit have some features that can be used for comparisons with other taxa described in the literature. In the caudal vertebra CCC 010 (Figure 3C), the neural arch is placed on the anterior portion of the centrum, which can be regarded as a titanosaur feature. This morphology is reported for titanosaur caudal vertebrae by Calvo \& Bonaparte (1991), Salgado et al. (1997), and Powell (2003). On the other hand, the neural arch is placed nearly on the mid-length of the caudal vertebrae in other sauropods (Salgado et al., 1997). The amphicoelous ends such as those present in CCC 010 are common in basal titanosaurs. Differently, in apical titanosaurs the caudal vertebrae are procoelous, with a ball-and-socket joint (Salgado et al., 1997). Moreover, this specimen is similar to the caudal centrum described by Medeiros \& Schultz (2001) from the Alcântara Formation, which was regarded as a basal titanosaur. According to Medeiros \& Schultz (2001), the caudal centrum from the Alcântara Formation also has an anteriorly placed neural arch, slightly amphicoelous ends, and slightly concave lateral faces.

Among basal titanosaurs, the morphology described in CCC 010 is closer to that of the caudals reported for Malawisaurus dixeyi by Jacobs et al. (1993) and Gomani (2005) from Aptian deposits of Malawi. Andesaurus delgadoi from the Albian-Cenomanian Rio Limay Formation (Calvo \& Bonaparte, 1991) also bears amphicoelous or amphiplatyan caudal vertebrae as in CCC 010. However, in Andesaurus the caudal vertebrae are more laterally compressed than in CCC 010. Moreover, other basal titanosaurs having amphiplatyan mid-caudals have been described recently such as Mendozasaurus (González Riga, 2003), which precludes the assignment of CCC 010 to one of these taxa only based on caudal vertebra joint morphology.

The bone tissue in CCC 053 and CCC 074 (Figure 3A, B) corresponds to a well-developed pneumatic tissue composed by chambers and small internal coels which, following the nomenclature proposed by Wedel (2003), are regarded as camerate and polycamerate (cameral generations usually 3 or more, with increased number of branches at each generation). 
This well-developed system of chambers and internal coels can be also regarded as a titanosaur feature (Wedel, 2005).

The presence of neural spine with well-developed pneumatic tissue has been reported only for apical titanosaurs (Salgado et al., 1997; Upchurch, 1998; Wilson \& Sereno, 1998) such as Alamosaurus, Opisthocoelicauda, and Saltasaurinae. Within Saltasaurinae, Saltasaurus has camellate presacral, sacral, and anterior caudal vertebrae (Powell, 1992 sensu Wedel, 2005). Camellate caudal vertebrae are considered to be a synapomorphy for Saltasaurinae (Salgado et al., 1997). In basal sauropods such as Barapasaurus and Haplcanthosaurus, except for Mamenchisaurus which has camellate presacral vertebrae, the vertebral pneumaticity is limited to the presence of large fossae or foramens in the lateral faces of the centra (Britt, 1993, 1997; Wedel, 2003).

The fragmentary proximal end of the humerus CCC 005 (Figure 3D) shares with both apical and basal titanosaurs as Rapetosaurus krausei (Curry Rogers \& Forster, 2001), Aeolosaurus rionegrinus (Salgado \& Coria, 1993), Mendozasaurus neguyelap (González Riga, 2003), and Malawisaurus dixeyi (Gomani, 2005) the presence of straight laterodorsal margins which meet in a right angle and strongly developed curvature on the medial margin of the humerus.

The occurrences of Titanosauria show that they were more diverse and abundant in Cretaceous deposits from Argentina, mainly in Patagonia. In Brazil, titanosaurs are more common in Campanian/Maastrichtian deposits from the states of São Paulo, Minas Gerais, Mato Grosso and Goiás (Candeiro, 2006; Candeiro et al., 2005; Bonaparte, 1994; Salgado et al., 1997; Bertini et al., 2001; Powell, 2003; Santucci $\&$ Bertini, 2006). On the other hand, titanosaurs are rarely found in pre-Campanian/Maastrichtian deposits, and they are only known from the Alcântara Formation, São Luís-Grajaú Basin (Medeiros \& Schultz, 2001) so far. The best remains collected from this unit correspond to vertebral centra and limb bones. Based on the morphology of these remains, Medeiros \& Schultz (2001) considered them similar to Andesaurus and Malawisaurus. Although the fossils unearthed from the São Luís-Grajaú Basin cannot be assigned to any titanosaur species because of their poor preservation quality, these remains show that basal titanosaurs were present in north-northeastern Brazil at least in AlbianCenomanian times.

The features seen in the fragments of neural arches, CCC 017 and CCC 030 (Figure 4A, B), and the fragment of neural spine (CCC 060, Figure 4C) indicate they are more similar to rebbachisaurids. The neural spines are high and form a cross pattern together with the pre and postspinal laminae. These features were previously reported for rebbachisaurids by Calvo \& Salgado (1995), Carvalho et al. (2003), Medeiros \& Schultz (2004), and Salgado et al. (2004).

Although fragmentary, the remains described here correspond to new evidence about the presence of rebbachisaurids in Albian-Cenomanian deposits of the São Luís-Grajaú Basin. Previous findings were collected from deposits of the Alcântara Formation, which is Cenomanian in age, and essentially correspond to isolated caudal centra and neural arches (Medeiros \& Schultz, 2001). These same authors considered these fossils more related to African than to American sauropods.

Amazonsaurus maranhensis from the Albian Itapecuru Formation (Carvalho et al., 2003) was described on the basis of a partial skeleton, principally dorsal and caudal centra and hemal arches. Unfortunately, there are not enough overlapping bones to compare the fossils from the Undifferentiated Unit to this species.

\section{CONCLUSION}

Sauropod remains from the Undifferentiated Unit deposits, lower/middle Albian, Itapecuru Group, São Luís Grajaú Basin, Maranhão State, are described for the first time. This unit is overlaid by the Alcântara Formation where sauropods have already been reported. The fragmentary nature of these remains does not allow a species level taxonomic assignment. However, according to the morphology of these remains, we can regard them as being titanosaurs and rebbachisaurids. Although these taxa have already been found in the Alcântara Formation, it is not possible to assign them to the same species because there are no overlapping bones for direct comparison.

Unfortunately, because of the inadequate collecting methods (the remains had been collected by local landowners), we cannot assure the exact stratigraphic position of these fossils, and therefore, it is not clear if the two taxa inhabited the same area in the same age interval. Further studies in this area may furnish additional evidence about this association of different sauropod taxa, which is unusual for titanosaurs because they generally represent the only sauropod taxon in a given sedimentary deposit.

The titanosaurs found in the Undifferentiated Unit are coeval to the global record of basal titanosaurs such as Andesaurus (Argentina, Albian-Cenomanian) and Malawisaurus (Malawi, Aptian). Unfortunately, the morphological similarities among Maranhão titanosaurs and Andesaurus and Malawisaurus are also shared with other titanosaurs, precluding their assignment to any specific taxa.

Finally, the presence of titanosaurs and rebbachisaurids in deposits of the Undifferentiated Unit represents the oldest record of these taxa in Brazil so far.

\section{ACKNOWLEDGMENTS}

We thank the Municipality of Coroatá for kindly facilitating our access to the fossils described here. We also thank A. Pereira (CPHNA-MA) for her help during the field trips; and two anonymous reviewers. The senior author was awarded a scholarship from CAPES.

\section{REFERENNCIAS}

Bertini, R.J.; Santucci, R.M. \& Arruda-Campos, A.C. 2001. Titanossauros (Sauropoda: Saurischia) no Cretáceo Superior 
continental (Formação Marília, Membro Echaporã) de Monte Alto, Estado de São Paulo, e correlação com formas associadas do Triângulo Mineiro. Geociências, 20(1/2):93-103.

Britt, B.B. 1993. Pneumatic postcranial bones in dinosaurs and other archosaurs. University of Calgary, Tese de Doutorado, 383 p.

Britt, B.B. 1997. Postcranial pneumaticity. In: P.J.Currie \& K.Padian (eds.) The Encyclopedia of Dinosaurs, Academic Press, p. 590593.

Bonaparte, J.F. 1994. Dinosaurios de América del Sur. Museu Argentino de Ciências Naturales, Buenos Aires, 174 p.

Candeiro, C.R.A. 2006. Los Titanosaurideos (Dinosauria, Titanosauria) del Grupo Bauru y sus relaciones paleogeográficas con los géneros de la Patagonia Argentina. Sociedade \& Natureza, 34(18):77-89.

Candeiro, C.R.A.; Santos, A.R.; Rich, T.H.; Marinho, T.S. \& Oliveira, E.C. 2005. Vertebrate fossils from the Adamantina Formation (Late Cretaceous), Prata paleontological district, Minas Gerais State, Brazil. Geobios, 39(3):319-327.

Calvo, J.O. \& Bonaparte, J.F. 1991. Andesaurus delgadoi gen. et sp. nov. (Saurischia, Sauropoda) dinosaurio Titanosauridae de la Formação Rio Limay (Albiano-Cenomaniano), Neuquén, Argentina. Ameghiniana, 28:303-310.

Calvo, J.O. \& Salgado, L. 1995. Rebbachisaurus tessonei sp. nov. a new Sauropoda from the Albian-Cenomanian of Argentina: new evidence on the origin of the Diplodocidae. Gaia, 11:13-33.

Carvalho, I.S.; Avila, L.S. \& Salgado, L. 2003. Amazonsauros maranhensis gen. et sp. nov. (Sauropoda, Diplodocoidea) from the Lower Cretaceous (Aptian-Albian) of Brazil. Cretaceous Research, 24:697-713.

Castro, D.F.; Bertini, R.J.; Medeiros, M.A. \& Santucci, R.M. 2005. Fossils from the Coroatá locality, Unidifferentiated Geological Unity, Itapecuru Group, Lower/Middle Albian from the São LuísGrajaú Basin, Maranhão State, Noth/Norteastern Brazil. In: CONGRESSO LATINO-AMERICANO DE PALEONTOLOGIADE VERTEBRADOS, 2, 2005. Resumos, Rio de Janeiro, Museu Nacional/UFRJ, p.75-76.

Castro, D.F.; Toledo, C.E.V.; Sousa, E.P. \& Medeiros, M.A. 2004. Ocorrência de Asiatoceratodus (Osteichthyes, Dipnoiformes) na Formação Alcântara, eo-Cenomaniano da Bacia de São Luís, MA, Brasil. Revista Brasileira de Paleontologia, 7(2):245-248.

Cooper, M.R. 1984. Reassessment of Vulcanodon karibaensis Raath (Dinosauria: Saurischia) and the origin of the Sauropoda. Palaeontologia Africana, 25:203-231.

Curry Rogers, K. \& Forster, C.A. 2001. The last of the dinosaurs titans: a new sauropod from Madagascar. Nature, 412(2):530534.

Dutra, M.F.A. \& Malabarba, M.C.S.L. 2001. Peixes do AlbianoCenomaniano do Grupo Itapecuru no estado do Maranhão, Brasil. In: D.F.Rossetti; A.M. Góes \& W.Truckenbrodt (eds.) O Cretáceo da Bacia de São Luís-Grajaú, MPEG, p.191-208.

Góes, A.M. \& Rossetti, D.F. 2001. Gênese da Bacia de São LuísGrajaú, Meio Norte do Brasil. In: D. F. Rossetti; A. M. Góes \& W. Truckenbrodt (eds.) O Cretáceo na Bacia de São LuísGrajaú, MPEG, p.15-29.

Gomani, M.E. 2005. Sauropds dinosaurs from the Early Cretaceous of Malawi, África. Palaentologia Electronica 8(1):1-37.

González Riga, B.J. 2003. A new titanosaur (Dinosauria, Sauropodo) from the Upper Cretaceous of Mendoza Province, Argentina. Ameghiniana, 40(2):155-172.

Jacobs, L.L.; Winkler, D.A.; Downs, W.R. \& Gomani, E.M. 1993. New material of an Early Cretaceous titanosaurid sauropod dinosaur from Malawi. Palaeontology, 36:523-534.

Medeiros, M.A. \& Schultz, C.L. 2001. Uma paleocomunidade de vertebrados do Cretáceo Médio, bacia de São Luís. In: D.F.Rossetti; A.M. Góes, \& W. Truckenbrodt (eds.) O Cretáceo na Bacia de São Luís-Grajaú, MPEG, p. 209-221.

Medeiros, M.A. \& Schultz, C.L. 2004. Rayososaurus (Sauropoda, Diplodocoidea) no Meso-Cretáceo do norte-nordeste brasileiro. Revista Brasileira de Paleontologia, 7(2):275-279.

Pedrão, E.; Arai, M.; Barrilari, I.M.R. \& Carvalho, I.S. 1993a. Análise palinológica de uma amostra de superficie de Querru (Formação Itapecuru), Município de Itapecuru-Mirim - MA. Rio de Janeiro, Petrobras, 11 p. (Relatório Técnico).

Pedrão, E.; Arai, M.; Carvalho, I.S. \& Ferreira, C.S. 1993 b. Palinomorfos de sedimentos albianos (Formação Itapecuru) da Bacia do Parnaíba. Rio de Janeiro, Petrobras, Cenpes, 13 p. (Relatório Técnico).

Powell, J.E. 1986. Revisión de los Titanosauridos de America del Sur. Universidad Nacional de Tucumán, Tese de Doutorado, $493 \mathrm{p}$.

Powell, J.E. 2003. Revision of South American titanosaurid dinosaurs: paleobiological, paleobiogeographical and phylogenetic aspects. Records of the Queen Victoria Museum 111:1-173.

Rossetti, D.F. 2003. Bacia de São Luís-Grajaú. Fundação Paleontológica Phoenix, (58):1-9.

Rossetti, D.F. 2001. Arquitetura deposicional da Bacia de São LuísGrajaú. In: D.F.Rossetti; A.M. Góes \&W.Truckenbrodt (eds.) O Cretáceo na Bacia de São Luís-Grajaú, MPEG, p. 31-46.

Rossetti, D.F. \& Truckenbrodt, W. 1997. Revisão estratigráfica para os depósitos do Albiano-Terciário Inferior (?) na Bacia de São Luís (MA), Norte do Brasil. Boletim do Museu Paraense Emílio Goeldi (Série Ciências da Terra), 9:29-41.

Santucci, R.M. \& R.J. Bertini, 2006. A new titanosaur from western São Paulo State, Upper Cretaceous Bauru Group, south-east Brazil. Palaeontology, 49(1):59-66.

Salgado, L. \& Coria, R.A. 1993. El género Aeolosaurus (Sauropoda, Titanosauridae) en la Formácion Allen (CampanianoMaastrichtiano) de la Provincia de Rio Negro, Argentina. Ameghiniana, 30(2):119-128.

Salgado, L; Coria, R.A. \& Calvo, J.O. 1997. Evolution of titanosaurid sauropods. I: Phylogenetic analysis based on the postcranial evidence. Ameghiniana, 34(1):3-32.

Salgado, L.; Garrido, A.; Cocca, S.E. \& Cocca, J.R. 2004. Lower Cretaceous Rebbachisaurus suropods from Cerro Aguada Del Leon (Lohan Cura Formation), Neuquén Province, Northwestern Patagonia, Argentina. Journal of Vertebrate Paleontology, 24(4):903-912.

Upchurch, P. 1998. The evolutionary history of sauropod dinosaurs. Zoological Journal of the Linnean Society, 124:43-103.

Wedel, M.J. 2005. Postcranial skeletal pneumaticity in sauropods and its implications for mass estimates. In: J.A.Wilson \& K. Curry-Rogers (eds.) The Sauropods: Evolution and Paleobiology, University of California Press, p. 201-228.

Wedel, J.M. 2003. The evolution of vertebral pneumaticity in sauropod dinosaurs. Journal of Vertebrate Paleontology, 23(2):344-357.

Wilson, J.A. \& Sereno, P.C. 1998. Early evolution and higher-level phylogeny of sauropod dinosaurs. Society of Vertebrate Paleontology, 68 p. (Memoir 5).

Received in July, 2006; accepted in October, 2007. 